\title{
The development of island lakes of Lake Ladoga during the Late Pleistocene - Holocene
}

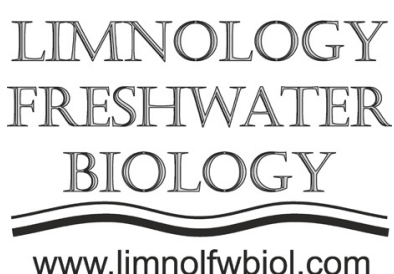

\begin{abstract}
Sapelko T.V.*, Kuznetsov D.D., Ludikova A.V., Korneenkova N.Yu., Terekhov A.V. Institute of Limnology, Russian Academy of Sciences, 9, Sevastyanova str., Saint-Petersburg, 196105, Russia

ABSTRACT. Lake Ladoga, the largest lake in Europe, has about 500 islands. In the northen part of Lake Ladoga, the large islands have small lakes that gradually were isolated from Ladoga during the Holocene. In recent years, we have obtained the results of the lakes sediments studies in the Putsaari, Lunkulansaari and Valaam islands. We present the results of lithological, radiocarbon, pollen, macrofossil and diatom analyzes of islands lakes' sediments sequences. The island lakes have the features associated which eliminates some of the factors influencing the development of these lakes' ecosystems. And therefore island lakes are a unique archive for the reconstruction of the paleoenvironment
\end{abstract}

Keywords: lake sediments, Ladoga islands, AMS data, multi-proxy analysis

\section{Introduction}

At ca 11700 cal BP, Lake Ladoga was an easternmost extension of the Baltic Ice Lake. The shoreline of Baltic Ice Lake reached ca 50-60 m a.s.1. The emergence of the Ancylus Lake at around 10700 cal BP. The Ancylus Lake level was about 15-25 meters. The beginning with 5900 cal BP the Lake Saimaa started to drain into the Lake Ladoga via the Vuoksa River. The resulting influx of fresh water led to the rapid rise of the Ladoga Lake and thus contributed to the ensuing Ladoga transgression. The maximum Ladoga transgression level was about 15-22 m a.s.l. (Saarnisto, Grönlund, 1996; Subetto, 2009; Saarnisto, 2012). The present Ladoga water level is $5 \mathrm{~m}$ a.s.l.

According to the studies of the small lakes at the islands Valaam (Vuorela et al., 2001), Mantsinsaari (Delusin, Donner, 1995), Riekkalansaari (Alenius et al., 2004), Kilpolansaari (Saarnisto, Grönlund, 1996) and Putsaari (Ludikova et al., 2005) at the Lake Ladoga were isolated from Lake Ladoga at different times during the Holocene.

\section{Materials and methods}

Multi-proxy paleolimnological studies have been carried out on the islands of Putsaari, Lunkulansaari and Valaam by the Institute of Limnology, the Russian Academy of Sciences, for ten years. On the Putsaari Island (Sapelko et al., 2014) we studied lakes Laurinlampi (St. Sergey) (15.8 m a.s.l.), Tervalampi (21m a.s.l.) Vuorenlampi (49 m a.s.l.) and Pikalalampi (57 $\mathrm{m}$ a.s.l.). On the Lunkulansaari Island (Sapelko et al., 2018) we studied lakes Kuikkalampi (17 m a.s.l.), Sokkasenlampi (14 m a.s.l.) and Hovatanlampi (10 $\mathrm{m}$ a.s.1.). On the Valaam Island we studied lakes Antonievskoye (13 m a.s.l.) and Vitalievskoye (10,8 m a.s.l.). Lakes' sediments studied included lithological, radiocarbon, pollen, macrofossil and diatom analyzes. All used radiocarbon datings of lakes isolation were calibrated using a general IntCal13 calibration curve using OxCal version 4.3 software (Bronk Ramsey, 2009; Reimer et al, 2013).

\section{Results}

According to our reconstruction ca. $3100 \pm 200$ cal. BP. Lake Kuikkalampi and Lake Sokkasenlampi on the Lunkulansaari Island, as well as Lake Kirkkolampi (19 $\mathrm{m}$ a.s.l.) in the north of a large swamp in the central part of the Mantsinsaari Island (Delusin and Donner, 1995) were isolated from Lake Ladoga. Ca $2800 \pm$ 200 cal BP Lake Peipposenlampi (9 m a.s.l.) on the Mantsinsaari Island and Lake Hovatanlampi on the Lunkulansaari Island were also isolated.

Lake Antonievskoe located above the rest of the lakes of the Valaam Island was isolated from Lake Ladoga ca. $3100 \pm 200 \mathrm{cal} \mathrm{BP}$. Lake Vitalievskoe at the Valaam Island was isolated from Lake Ladoga ca. 2800 $\pm 200 \mathrm{cal} \mathrm{BP}$. The small lakes at the Valaam Island emerged from Lake Ladoga when the water level fell $12 \mathrm{~m}$ in connection of the formation of River Neva, the current outlet of the lake (Saarnisto, 2012).

Previously, $9842 \pm 61 \mathrm{C}^{14}$ years ago (ca. 11270 cal BP) Lake Picalalampi on the island of Putsaari was isolated. The established isolation time of Lake 
Vuorenlampi is $9004+56 \mathrm{C}^{14}$ (ca 10140 cal BP). Then $8570 \mathrm{C}^{14}$ years ago, Lake Tervalampi was isolated. Isolation of Lake Laurinlampi was took place $2740 \pm$ $70 \mathrm{C}^{14}$ (ca. 2848 cal BP).

\section{Conclusions}

As a result of our paleolimnological studies at the islands of Lake Ladoga, stages of small island lakes isolation from Lake Ladoga during the Holocene were established. The new data gave us the opportunity to reconstruct the time, isolation conditions, as well as the development of lakes after isolation

\section{Acknowledgements}

The study was carried out within the framework of the State Research Program of the Institute of Limnology, RAS No. 0154-2019-0001.

\section{References}

Alenius T., Grönlund E., Simola H., Saksa A. 2004. Land-use history of Riekkalansaari Island in the northern archipelago of Lake Ladoga, Karelian Republic, Russia. Vegetation History and Archaeobotany 13: 23-31.

Bronk Ramsey C. 2009. Bayesian analysis of radiocarbon dates. Radiocarbon 51(1): 337-360.

Delusin I., Donner J. 1995. Additional evidence of the Holocene transgression in Lake Ladoga on the basis of an investigation of the beach deposits on the island of Mantsinsaari. Bulletin of the Geological Society of Finland: 39-50.

Ludikova A.V., Subetto D.A., Davydova N.N. et al. 2005. Lake Ladoga level changes in the Holocene (based on the paleolimnological studies of St Sergey Lake at Putsaari Island). Izvestiya RGO [Proceedings of the Russian Geographic Society] 137(6): 34-41. (in Russian)

Reimer P.J., Bard E., Bayliss A., et al. 2013: IntCal13 and Marine13 Radiocarbon Age Calibration Curves 0-50,000 Years cal BP. Radiocarbon. 55(4): 1869-1887.

Saarnisto M. 2012. Late Holocene land uplift/neotectonics on the island of Valamo (Valaam), Lake Ladoga, NW Russia. Quaternary International. 260: 143-152.

Saarnisto M., Grönlund T. 1996. Shoreline displacement of Lake Ladoga - new data from Kilpolansaari. Hydrobiologia 322: 205-215.

Sapelko T.V., Kuznetsov D.D., Korneenkova N.Yu. et al. 2014. Paleoliminology of the internal lakes of Putsaari Island (Lake Ladoga). Izvestiya RGO [Bulletin of the Russian Geographical Society] 146 (3): 29-40 (in Russian).

Sapelko T.V., Terekhov A.V., Gazizova T.Yu. et al. 2018. Paleolimnology of Lunkulansaari Island, Lake Ladoga: preliminary results. In: International conference "Freshwater ecosystems - modern challenges". Irkutsk, pp. 295-296.

Subetto D.A. 2009. Lake sediments: paleolimnological reconstructions. St. Petersburg: Publishing House of Herzen State Pedagogical University. (in Russian)

Vuorela I., Lempiäinen T., Saarnisto M. 2001. Land use pollen record from the Island of Valamo, Russian Karelia. Annales Botanici Fennici 38: 139-165. 